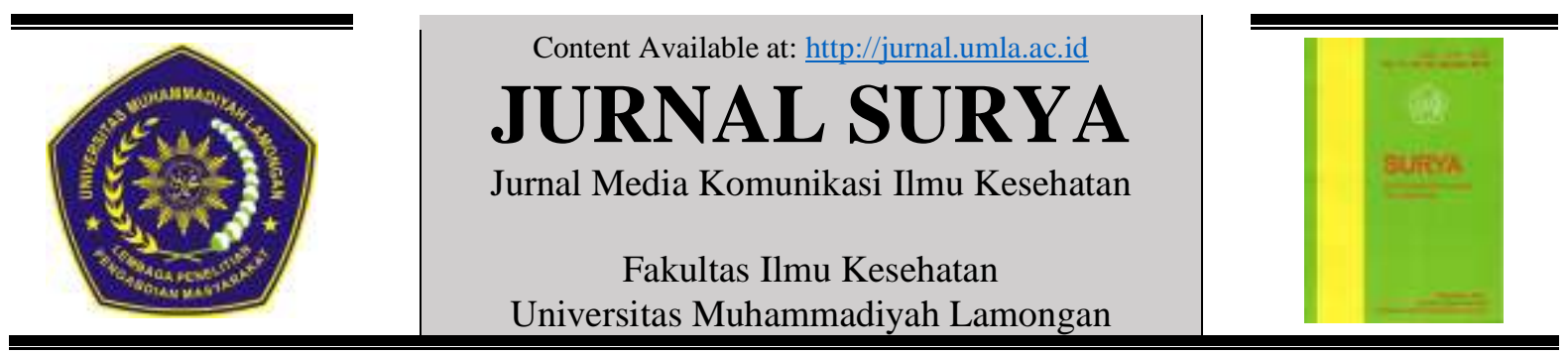

\title{
Gambaran Pengetahuan Lansia tentang Diet Asam Urat di Wilayah Kerja Puskesmas Kertasemaya Tahun 2018
}

Dedeh Husnaniyah

Keperawatan STIKes Indramayu Jawa Barat

\section{ARTIKEL INFO}

Article History:

\section{Kata Kunci:}

Pengetahuan

Lansia

Diet

Asam Urat

\begin{abstract}
ABSTRAK
Background: Asam urat adalah peradangan akibat adanya endapan kristal asam urat pada sendi dan jari. Asam urat yang berlebih dapat menyebabkan pembengkakan, kemerahan, nyeri hebat, panas dan gangguan gerak pada penderitanya. Penderita terbanyak asam urat adalah lansia dan akan bertambah parah apabila disertai dengan pola konsumsi makanan yang tidak seimbang. Salah satu upaya untuk menurunkan kadar asam urat adalah dengan diet yang baik dan keberhasilan diet pada lansia berhubungan erat dengan pengetahuan yang dimilikinya.
\end{abstract}

Objectives: Tujuan penelitian ini adalah untuk mengidentifikasi pengetahuan lansia tentang diet asam urat dalam upaya menurunkan kadar asam urat di wilayah kerja puskesmas Kertasemaya tahun 2018.

Design: Penelitian ini merupakan penelitian kuantitatif dengan pendekatan deskriptif. Populasi pada penelitian ini lansia yang terdiagnosis asam urat di wilayah kerja Puskesmas Kertasemaya. Pengambilan sampel dilakukan dengan teknik porposive sampling sebanyak 104 responden. Instrument penelitian ini adalah kuesioner yang di buat oleh peneliti dan analisa data yang digunakan adalah analisia univariat.

Results: Hasil penelitian menunjukan bahwa dari 104 responden, perempuan lebih banyak yang menderita asam urat dibandingkan laki-laki sebanyak $70,2 \% \quad(73$ responden), presentase usia responden paling banyak pada usia $\leq 55$ tahun yaitu 52,8\% (55 responden), presentase pendidikan responden paling banyak Sekolah Dasar yaitu 66,3 (69 responden) dan responden yang memiliki pengetahuan baik lebih banyak dibandingkan dengan responden yang memiliki pengetahuan cukup dan kurang yaitu 45,2\% (47 responden).

Conclusions: Lansia dengan asam urat di wilayah kerja puskesmas Kertasemaya lebih banyak yang memiliki pengetahuan yang baik. Hasil penelitian ini diharapkan petugas kesehatan dapat menganalisis faktor lainnya yang dapat menurunkan kadar asam urat. 
PENDAHULUAN

Asam urat merupakan hasil metabolisme akhir dari purin yaitu salah satu komponen asam nukleat yang terdapat dalam inti sel tubuh. Peningkatan kadar asam urat dapat mengakibatkan gangguan pada tubuh manusia seperti perasaan linu-linu di daerah persendian dan sering disertai timbulnya rasa nyeri yang teramat sangat bagi penderitannya. Penyakit ini sering disebut gout atau lebih dikenal dengan asam urat (Andry, 2009).

Asam urat muncul sebagai serangan peradangan sendi yang timbul berulang-ulang. Gejala khas dari serangan asam urat adalah serangan akut dengan gejala pembengkakan, kemerahan, nyeri hebat, panas dan gangguan gerak. Lokasi yang paling sering pada serangan pertama adalah pada pangkal ibu jari kaki (Syarif, 2012)

Seseorang akan dikatakan menderita asam urat jika kadar asam urat dalam darahnya di atas $7 \mathrm{mg} / \mathrm{dl}$ pada laki- laki dan diatas $5 \mathrm{mg} / \mathrm{dl}$ pada wanita. Penyakit asam urat terjadi jika timbunan kristal asam urat yang mengendap dalam persendian meningkat. Peningkatan tersebut dapat disebabkan ginjal yang mengalami gangguan membuang asam urat dalam jumlah yang banyak (Fatmah, 2010).

Menurut World Health Organization (WHO) tahun 2013 prevalensi penyakit asam urat pada populasi di USA diperkirakan $13,6 / 100.000$ penduduk. Penyakit asam urat di Indonesia berdasarkan Riset Kesehatan Dasar (Riskesdas) tahun 2013 sebesar 11,9\%, sedangkan menurut tenaga kesehatan penderita asam urat mencapai angka 24,7\% apabila dilihat dari diagnosis atau gejala (Sukarmin, 2015). Menurut hasil laporan Dinas Kesehatan Kabupaten Indramayu (2016) penderita asam urat terbanyak terdapat di Wilayah Kerja Puskesmas di Indramayu berjumlah 1.248 dan pada Wilayah Kerja Puskesmas Kertasemaya dengan jumlah 140 orang yang terkena asam urat.

Penyakit asam urat semakin meningkat dengan bertambahnya usia. Risiko terjadinya asam urat pada lansia akan bertambah apabila disertai dengan pola konsumsi makanan yang tidak seimbang. Banyaknya makanan tinggi purin yang dikonsumsi akan memperbesar risiko terkena asam urat (Sylvia, 2006). Sehingga untuk menurunkan kadar asam urat dibutuhkan pengetahuan yang baik tentang diet asam urat. Tujuan penelitian ini adalah untuk mengetahui pengetahuan lansia tentang diet asam urat dalam upaya menurunkan kadar asam urat di wilayah kerja puskesmas Kertasemaya Indramayu tahun 2018.

\section{METODE PENELITIAN}

Penelitian ini merupakan penelitian kuantitatif dengan pendekatan deskriptif . Populasi dalam penelitian ini adalah lansia yang terdiagnosis asam urat dan tinggal di wilayah kerja Puskesmas Kertasemaya Kabupaten Indramayu. Jumlah populasi penelitian ini sebanyak 140 lansia.

Pengambilan sample pada penelitian ini dilakukan dengan tekhnik Purposive sampling sebanyak 104 responden dengan kriteria inklusi, yaitu lansia yang terdiagnosis asam urat, berusia 45-90 tahun, dapat berkomunikasi dengan baik dan mampu membaca dan menulis.

Penelitian di laksanakan di wilayah kerja puskesmas Kertasemaya Indramayu pada 25 Juni - 7 Juli 2018. Instrumen penelitian yang digunakan adalah kuesioner yang dibuat oleh peneliti dan telah dilakukan uji validitas dan reliabilitas.

\section{HASIL PENELITIAN}

\section{Data Umum}

Tabel 1 Karakteristik Responden

\begin{tabular}{|c|c|c|c|}
\hline No & Data Umum & $\mathbf{F}$ & $\%$ \\
\hline & Umur Lansia & & \\
\hline 1 & Lansia Awal $\leq 55$ & 44 & 42,3 \\
\hline \multirow[t]{2}{*}{2} & Lansia Akhir > 55 & 60 & 57,7 \\
\hline & Jenis Kelamin & & \\
\hline 1 & Pria & 31 & 29,8 \\
\hline \multirow[t]{2}{*}{2} & Wanita & 73 & 70,2 \\
\hline & Pendidikan Lansia & & \\
\hline 1 & SD & 69 & 66,3 \\
\hline 2 & SMP & 12 & 11,5 \\
\hline 3 & SMA & 17 & 16,3 \\
\hline 4 & Perguruan Tinggi & 6 & 5,8 \\
\hline \multicolumn{2}{|c|}{ Total } & 104 & 100 \\
\hline
\end{tabular}


2. Data Khusus

Tabel 2 Distribusi Frekuensi Pengetahuan Lansia tentang Diet Asam Urat di Wilayah Kerja Puskesmas Kertasemaya Indramayu

\begin{tabular}{clcc}
\hline No & Kriteria & F & \% \\
\hline 1 & Baik & 47 & 45,2 \\
2 & Cukup & 31 & 29,8 \\
3 & Kurang & 26 & 25 \\
\hline \multicolumn{2}{l}{ Total } & $\mathbf{1 0 4}$ & $\mathbf{1 0 0}$ \\
\hline
\end{tabular}

Sumber: Data Primer, 2017

Tabel 3 Distribusi Frekuensi Pengetahuan Lansia tentang Diet Asam Urat berdasarkan usia di Wilayah Kerja Puskesmas Kertasemaya Indramayu $(\mathrm{n}=104)$

\begin{tabular}{ccccccc}
\hline \multirow{2}{*}{ Usia } & \multicolumn{6}{c}{ Pengetahunan Diet Lansia } \\
\cline { 2 - 7 } & \multicolumn{2}{c}{ Baik } & \multicolumn{1}{c}{ Cukup } & \multicolumn{1}{c}{ Kurang } \\
\cline { 2 - 7 } & F & \% & F & \% & F & \% \\
\hline Lansia Awal $\leq 55$ & 39 & 52 & 5 & 20 & 0 & 0 \\
Lansia Akhir $>55$ & 36 & 48 & 20 & 80 & 4 & 100 \\
\hline
\end{tabular}

Tabel 4 Distribusi Frekuensi Pengetahuan Lansia tentang Diet Asam Urat berdasarkan Jenis Kelamin di Wilayah Kerja Puskesmas Kertasemaya Indramayu ( $\mathrm{n}=104)$

\begin{tabular}{lcccccc}
\hline \multirow{2}{*}{$\begin{array}{c}\text { Jenis } \\
\text { Kelamin }\end{array}$} & \multicolumn{3}{c}{ Pengetahunan Diet Lansia } \\
\cline { 2 - 7 } & \multicolumn{2}{c}{ Baik } & \multicolumn{2}{c}{ Cukup } & \multicolumn{1}{c}{ Kurang } \\
\cline { 2 - 7 } & F & $\boldsymbol{\%}$ & F & \% & F & \% \\
\hline Pria & 22 & 29,3 & 7 & 28 & 2 & 50 \\
Wanita & 53 & 70,7 & 18 & 72 & 2 & 50 \\
\hline
\end{tabular}

Tabel 5 Distribusi Frekuensi Pengetahuan Lansia tentang Diet Asam Urat berdasarkan Tingkat Pendidikan di Wilayah Kerja Puskesmas Kertasemaya Indramayu ( $\mathrm{n}=104)$

\begin{tabular}{lcccccc}
\hline \multirow{2}{*}{$\begin{array}{c}\text { Tingkat } \\
\text { Pendidikan }\end{array}$} & \multicolumn{3}{c}{ Pengetahunan Diet Lansia } \\
\cline { 2 - 7 } & \multicolumn{2}{c}{ Baik } & \multicolumn{3}{c}{ Cukup } & \multicolumn{2}{c}{ Kurang } \\
\cline { 2 - 7 } & F & \% & F & \% & F & \% \\
\hline SD & 44 & 58,7 & 21 & 84 & 4 & 100 \\
SMP & 11 & 14,7 & 1 & 4 & 0 & 0 \\
SMA & 14 & 18,7 & 3 & 12 & 0 & 0 \\
PT & 6 & 8,0 & 0 & 0 & 0 & 0 \\
\hline
\end{tabular}


keadaan tersebut akan menyebabkan terjadinya peningkatan produksi asam urat dan penurunan ekskresi asam urat sehingga terjadi penumpukan kadar asam urat darah.

Berdasarkan Tabel 1 didapatkan bahwa pendidikan responden lebih banyak berpendidikan Sekolah Dasar (SD) sebanyak $69(66,3 \%)$ responden dibandingkan tingkat pendidikan yang lainnya, seperti Sekolah Menengah Pertama (SMP), Sekolah Menengah Atas (SMA) dan Perguruan Tinggi (PT). Tingkat pendidikan seseorang inilah yang akan mempengaruhi pengetahuan seseorang.

Pengetahuan adalah hasil tahu dan ini terjadi setelah orang mengadakan pengindraan (panca indra manusia : penglihatan, pendengaran, penciuman, rasa dan raba) terhadap suatu objek tertentu (Notoatmojo, 2010). Tingkat pengetahuan sangat dipengaruhi oleh beberapa faktor yaitu oleh tingkat pendidikan, informasi yang didapat oleh responden, sosial budaya setempat, lingkungan tempat tinggal, pengalaman yang dialami oleh lansia dan usia seseorang (Budiman, 2014). Berdasarkan Tabel 2 didapatkan bahwa dari 104 responden lebih banyak yang memiliki pengetahuan yang baik sebesar $47 \quad(45,2)$ responden dibanding responden yang memiliki pengetahuan yang cukup dan kurang. Pengetahuan pada penelitian ini adalah hasil tahu masyarakat tentang diet asam urat, meliputi jenis-jenis makanan yang dapat meningkatkan atau menurunkan terjadinya asam urat.

Usia merupakan faktor yang mempengaruhi pengetahuan. Artinya dimana umur semakin bertambah maka tingkat pengetahuan seseorang semakin menurun yang disebabkan oleh penurunan fungsi sensori persepsi, namun dengan batas usia tertentu (Notoatmodjo, 2010). Berdasarkan Tabel 3 menunjukkan bahwa lansia awal $(\leq 55$ tahun) memiliki pengetahuan yang baik tentang diet asam urat sebanyak $39(52,0 \%)$ dibandingkan lansia akhir (> 55 tahun).

Berdasarkan Tabel 4 menunjukkan bahwa hasil penelitian berdasarkan jenis kelamin didapatkan dari 104 responden wanita lebih banyak yang memiliki pengetahuan yang baik sebanyak $53(70,7 \%)$ dibandingkan dengan pria. Hal tersebut dimungkinkan karena banyaknya sarana informasi ataupun tersedianya layanan kesehatan yang lebih dekat dan lebih memadai.

Faktor lain yang ikut mempengaruhi pengetahuan seseorang adalah tingkat pendidikan. Tabel 5 menunjukan bahwa mayoritas tingkat pendidikan responden pada kategori pengetahuan baik adalah SD yaitu ada $44(58,7 \%)$ responden dari 104 lansia. Budiman (2014) menyatakan pendidikan merupakan suatu usaha untuk mengembangkan kepribadian dan kemampuan didalam dan diluar sekolah yang berlangsung seumur hidup. Diharapkan dengan memiliki pendidikan yang tinggi, maka seseorang makin mudah menerima informasi. Selain itu, semakin tinggi tingkat pendidikan seseorang diharapkan orang tersebut memiliki pengetahuan yang luas pula. Namun perlu diketahui bahwa seseorang yang berpendidikan rendah tidak berarti mutlak pengetahuan rendah. Dari pengalaman orang bisa mengingat dan menghafal mana yang dianjurkan dan yang tidak dianjurkan bagi penderita asam urat. Selain itu dengan kemajuan tehnologi dan informasi banyak edukasi kesehatan yang di informasikan melalui media elektronik serta tersedianya pelayanan kesehatan yang memadai dan dekat sehingga memudahkan masyarakat untuk manjangkaunya.

\section{KESIMPULAN dan SARAN}

\section{Kesimpulan}

1) Karakteristik responden didapatkan bahwa dari 104 responden lansia awal $(\leq 55$ tahun) lebih banyak menderita asam urat dibandingkan dengan lansia akhir (> 55 tahun), presentase jenis kelamin responden paling banyak wanita yaitu $73(70,2 \%)$, dan presentase pendapatan pendidikan responden paling banyak Sekolah Dasar sebanyak $69(66,3 \%)$.

2) Responden yang memiliki pengetahuan yang baik lebih banyak dibandingkan pengetahuan cukup dan kurang.

3) Lansia awal ( $\leq 55$ tahun) lebih banyak yang memiliki pengetahuan yang baik sebesar $39(52,0 \%)$ dibandingkan lansia akhir (> 55 tahun).

4) Wanita lebih banyak yang memiliki pengetahuan yang baik sebesar $53(70,7 \%)$ dibandingkan pria. 
5) Responden dengan tingkat pendidikan Sekolah Dasar lebih banyak yang memiliki pengetahuan baik sebanyak $44(58,7 \%)$ dibandingkan dnegan tingkat pendidikan yang lainnya.

\section{Saran}

Hasil penelitian ini di harapkan petugas kesehatan dapat menganalisis faktor lainnya untuk menurunkan asam urat.

\section{DAFTAR PUSTAKA}

Andry, Saryono dan Arif Setyo Upoyo. 2009. Analisis Faktor-Faktor Yang Mempengaruhi Kadar Asam Urat Pada Pekerja Kantor di Desa Karang Turi, Kecamatan Bumiayu, Kabupaten Brebes. Jurnal Keperawatan Soedirman (The Soedirman Journal of Nurshing). 4 (1: 26-31)

Budiman \& Riyanto Agus. 2014. Kapita Selekta Kuesioner, Pengetahuan dan Sikap dalam penelitian kesehata. Jakarta : Salemba Medika.

Dinas Kesehatan Kabupaten Indramayu. 2016. Profil Kesehatan Kabupaten. Indramayu. Indramayu: Dinas Kesehatan Indramayu.

Doherty, M 2009, New Insights Into The Epidemiology of Gout, Oxford Journals, pp. ii2-ii8

Fatmah. 2010. Gizi Usia Lanjut. Jakarta : Erlangga

Notoatmodjo. 2010. Ilmu Perilaku Kesehatan. Jakarta: Rineka Cipta

Riset Kesehatan Dasar (Riskesdas). 2013. Badan Penelitian dan Pengembangan Kesehatan Kementerian RI tahun 2013. Diakses: 29 September 2017, dari http://www.depkes.go.id

Roddy, E dan Doherty, M 2010, Epidemiology of Gout, Arthritis Research and Therapy, diakses 4 Agustus

2013 , http://arthritisresearch.com/content/12 $\underline{16 / 223}$

Suiraoka. IP. 2012. Penyakit Degeneratif Mengenal, Mencegah dan Mengurangi Faktor Resiko 9 Penyakit Degeneratif. Yogyakarta : Nuha Medika.

Sukarmin, 2015. Faktor-faktor Yang Berhubungan Dengan Kadar Asam Urat Dalam Darah Pasien Gout di Desa Kedungwinong Sukolilo Pati Yogyakarta; Global Health Science

Syarif L.O. 2012. Asuhan Keperawatan Gerontik, Yogyakarta : Nuha Medika

Sylvia, dkk 2006. Patofisiologi Konsep Klinis Proses-proses Penyakit- penyakit. Jakarta : EGC.

World Health Organization. 2013. A global brief on Gout. global public health crisis. 